\title{
THE ECONOMIC CONSEQUENCES OF CRIME AND OTHER ANTISOCIAL ACTIVITIES
}

\author{
Viktor Šoltés, ${ }^{1}$ Katarína Repková Štofková ${ }^{2}$
}

\begin{abstract}
Crime and other antisocial activities are the social phenomena that adversely affect the lives of people. Besides the negative impact on the quality of human life, the crime has a negative impact also on the economy. Damage caused by criminal acts can also be quantified in economic terms. This damage consists principally of the assets stolen from victims of crime, e.g. material damage. A substantial part of the damage also represents the financial losses that were caused by the economic crime. Another part of the damage is financial compensation provided by the state to the violent crime victims or their family members.

The paper deals with the analysis of the economically quantified damage caused by different types of crime in the Slovak Republic. The aim of this paper is to identify and analyze types of crimes that cause the largest economic losses and subsequently propose measures for elimination of critical types of crime to prevent greater economic losses.
\end{abstract}

JEL Classification Numbers: A12, H76; DOI: http://dx.doi.org/10.12955/cbup.v5.963

Keywords: Economic damage, crime, victim, financial losses, antisocial activities

\section{Introduction}

Several factors influence the quality of life. The most important are the socio-economic and security situation. Deterioration of the quality of life occurs when the state for its inhabitants cannot guarantee the required level of security. In this case, occurs searching for better living conditions and is increasing the risk of migration (Štofková, 2016). The consequence of leaving inhabitants abroad is the economic loss from them.

An indicator of the poor security situation is primarily crime and other antisocial activities. However, crime statistics cannot objectively evaluate the current criminal situation. Considering the latent (hidden) crime is necessary. Even though crime statistics are not an objective indicator of the current crime situation, it is a representative indicator useful for assessing the security situation.

Consequences of crime and other antisocial activities arise in the society a sense of fear, insecurity or worry for lives, health, and property of citizens. In addition to the psychological impact of crime, it has an adverse effect on the physical integrity of people. However, the society must realize that crime has a negative impact also on the economy.

For the state and society, it is necessary to recognize the economic impacts of crime. Monitoring the development of damage caused by each type of crime, it is possible to set priorities in the fight against crime. For the state, it is necessary to arrange that the damage caused by the crime will be the lowest which leads to better tax collection and acquisition of funds to the state budget. Then it will be possible to invest these funds in the development of society and thus improving the quality of life of the population.

\section{Crime}

As Gašpierik (2010) writes, crime and other antisocial activities is a negative social phenomenon that has various aspects. Their common feature is

- disruption of the harmonious development of society,

- disruption of existing law,

- disruption moral and moral values,

- disruption the desired development of personality (and thus the whole society),

- inciting an atmosphere of fear, anxiety, panic, mistrust, and insecurity.

The consequence of crime and other antisocial activities is damaged. According to Štofko \& Štofková (2011), victims suffer mainly physical and mental damage. Regarding society, it comes to the spiritual and material damage. In addition, in most cases, there is also the economic damage (caused to the victim or to the whole society).

\footnotetext{
${ }^{1}$ Faculty of Security Engineering, University of Žilina, Slovakia, Viktor.Soltes@fbi.uniza.sk

${ }^{2}$ Faculty of Operation and Economy of Transport and Communication, University of Žilina, Slovakia,

Katarina.Repkova@fpedas.uniza.sk
} 
Act no. 583/2008 Coll. on the Prevention of Crime and Other Anti-Social Activities says that crime is conduct that is a criminal offense. The criminal offense is an illegal act whose characteristics are given by the Criminal Code (Act no. 300/2005 Coll.). Act no. 583/2008 Coll. on the Prevention of Crime and Other Anti-Social Activities also defines other antisocial activities. It is conduct that is an offense or other administrative offense. For other antisocial activity, it is also possible to regard conduct that is not an offense or other administrative offense but hurts society.

Crime can be precisely expressed by specific quantitative and qualitative parameters. Phenomenology of the offense deals with examining these variables (Kubás, 2017). As Svetlík \& Vel'as (2016) say, among these variables, it is possible to include the structure of crime, which determines the proportion of each type of crime in the total number of the offenses committed at a certain time in a certain place. The structure of crime in the Slovak Republic consists of:

- violent crime,

- moral crime,

- property crime,

- other crime,

- residual crime,

- economical crime.

Figure 1 shows the evolution of the total number of each type of crime in Slovakia.

Figure 1: Development of different types of criminality in Slovakia

\section{The economic damage of selected types of crime}

Every kind of crime is specific by type of damage that is perpetrated. The economic damage is typical mainly for economic and property crime. However, the economic damage is also in the remaining types of crime (Šoltés, 2016). Its incidence is minimal (virtually zero) in the moral crime since it is a specific kind of crime, the consequences of which are mainly psychological but also physical and health.

Figure 2 shows the evolution of the economic damage to different types of crime in thousands $€$ in 20 years.

To the total economic damage caused by the crime have a dominant share economic crimes. Property crimes also cause greater economic damage. The largest economic damage was caused in 2003 when the amount of damage exceeded $€ 2$ billion. At present, the amount of damage has a downward trend and is about 400 million $€$. 


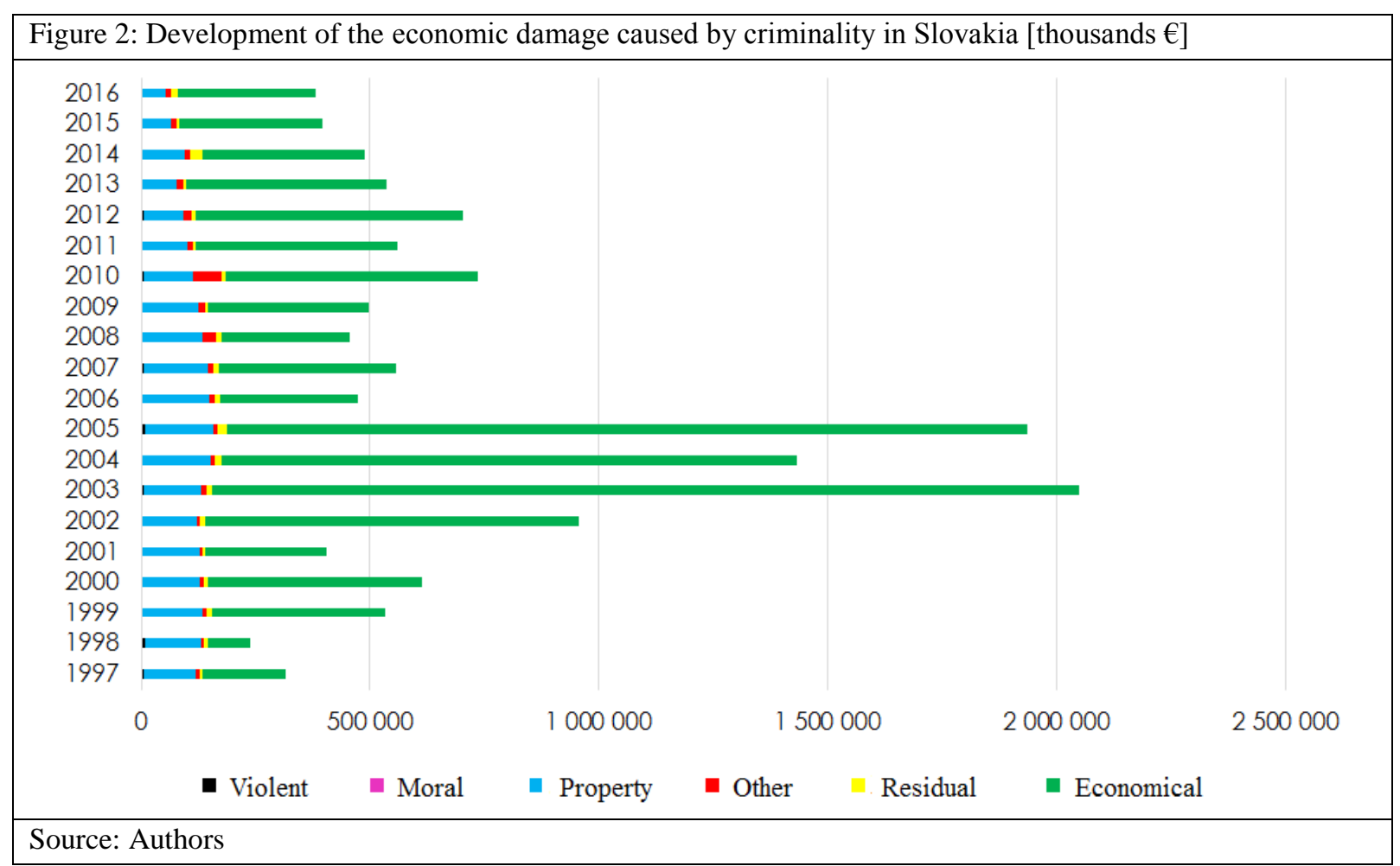

As Fomich (2016) writes, the offender of economic crime cannot be anyone, but only a person with particular social or economic status. The offender must have a high degree of intelligence and knowledge than needing the offender of another type of crime. A typical feature of economic crime is higher latency and rigorous investigation.

Committing economic crimes are committed far greater economic damages than committing another type of crime. Among typical economic criminal offenses belong Criminal Offence Endangering Market Economy, Criminal Offences against Economic Discipline, Currency and Tax Related Criminal Offences and Criminal Offences against Industrial Property Rights and Copyright.

Figure 3 shows the evolution of the economic damage of economic crimes in thousands $€$ in 20 years.

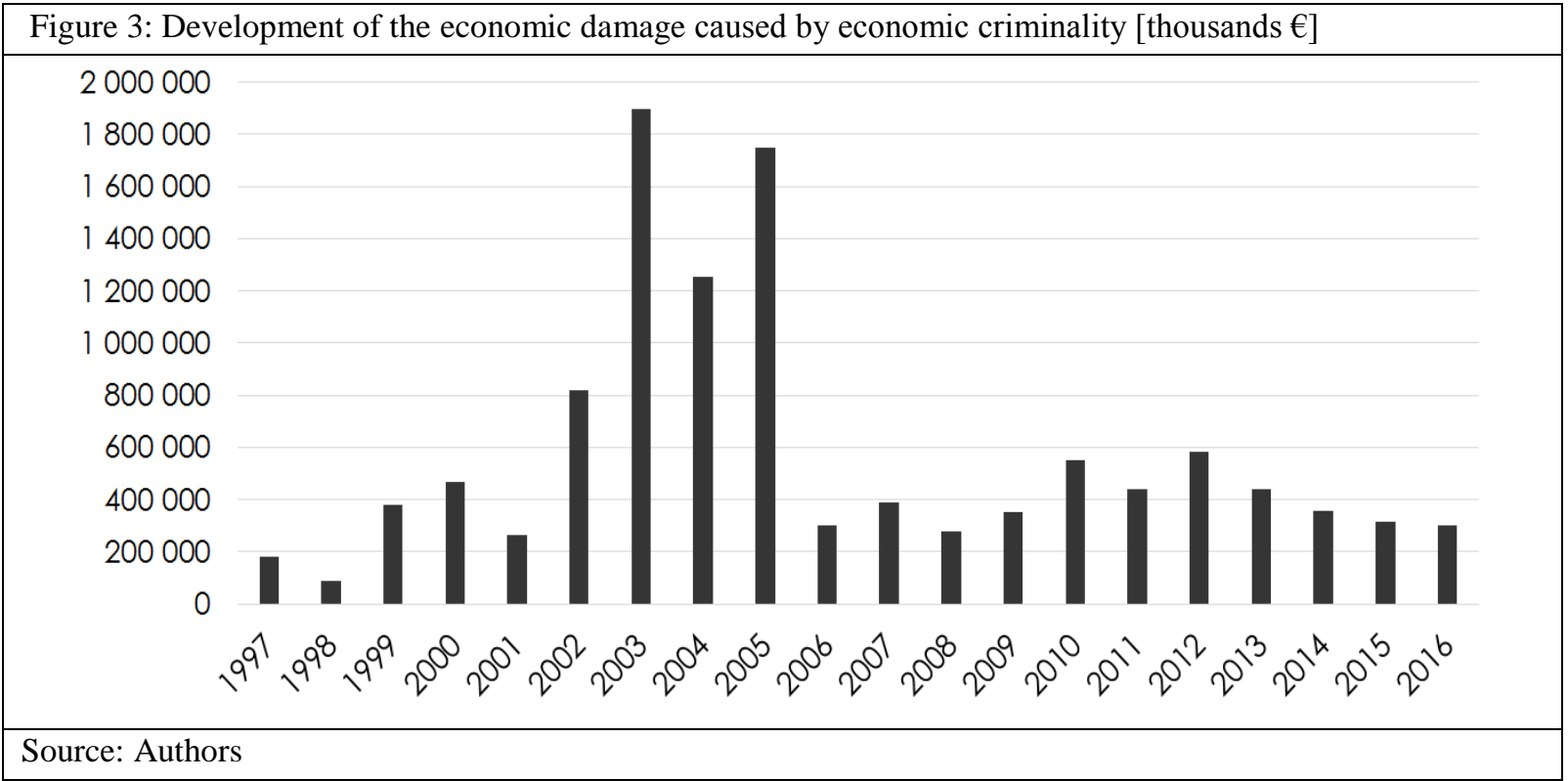

Development of the economic damage caused by economic crimes follows the development of the overall economic damage caused by the crime. Extremes were reached in 2002-2005. In the last ten 
years, the situation has stabilized, and economic damage does not exceed $€ 600$ million (in the last three years did not exceed $€ 400$ million).

Property crime has a major part of total crimes. Regarding the caused damage, it is the second most serious form of the offense. Figure 4 shows the evolution of the economic damage of property crime in thousands $€$ in 20 years.

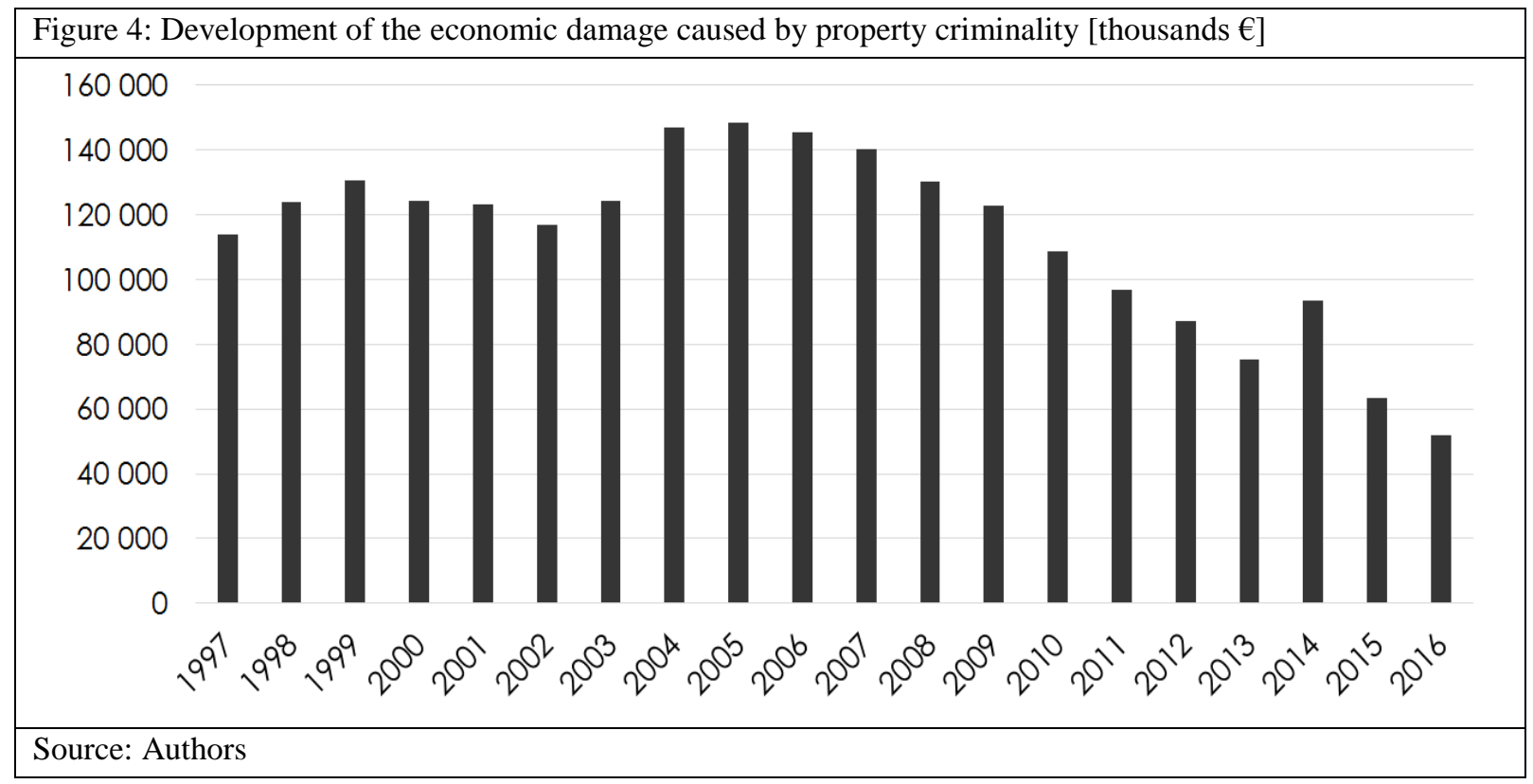

The aim of a property crime is profit taking of cash, securities or lucrative material goods. Among property crimes belong primarily criminal offenses of Theft, Embezzlement, various forms of Fraud, Unjust Enrichment, Sharing or Unlawful Manufacturing and Enjoyment of Payment Means, Electronic Money or Other Payment Cards (Baumann, 2013).

Evolution of economic damage caused by property crime is declining in the long term (except in 2014). The highest damage caused by property crimes (as with the economic crime) was achieved in 2004 and 2005 (nearly $€ 150$ million). In 2016, damage slightly exceeded $€ 50$ million. Regarding dynamics, it is necessary to point out that every year damage decreases by almost 20 million $€$.

\section{Conclusion}

Crime and other antisocial activity is a socio-pathological phenomenon that undermines the individual's life and development of the society. Crime can be objectively quantified by the number of registered crimes. Their number in recent years is steadily declining. Regarding the total number of crimes, it has dominant position property crimes.

Crime is a negative phenomenon as it causes various forms of damage, e.g. psychological damages, and damages to the physical integrity of the victim, but also economic damage. Evolution in recent years shows that the economic damage caused by crime has decreasing character. The peak was reached in 2003. Overall, the economic damage caused by crimes is in the hundreds of millions of $€$. This amount of funds cannot be considered as a negligible. Therefore, the state should do everything possible to avoid such high losses. The aim of the state should be to take preventive measures related to reducing the severity of the crimes (mainly economic, but also property). Among other things, the state should increase its activity in the field of detection and investigation of economic crime. However, it is necessary to take sufficiently effective measures in the field of generally binding legal regulations. In recent years, state policy focuses on improved tax collection and reducing tax evasion. The struggle with these negatives over the past few years is partly reflecting the reduction of the economic damage caused by the (economic) crime.

\section{Acknowledgment}

This paper was undertaken as part of the research project VEGA 1/0733/15, 1/0696/16 and IGP 201610. 


\section{References}

Act of the National Council of the Slovak Republic no. 300/2005 Coll. Criminal Code

Act of the National Council of the Slovak Republic no. 583/2008 Coll. on the Prevention of Crime and Other Anti-social Activities

Baumann, F., \& Friehe, T. (2013). Private protection against crime when property value is private information. International review of law and economics, 35, 73-79.

Fomich, V. A., (2016). Crimes in the sphere of economy: The organization and methods of investigation. Egal science and practice-bulletin of Nizhniy Novgorod academy of the Ministry of the interior of Russia, 2, 105-110.

Gašpierik, L. (2010). Prevencia kriminality a inej protispoločenskej činnosti [Prevention of Crime and Other Anti-social Activities] Kosice, Slovakia: Presses Multiprint.

Kubás, J., \& Štofková, Z. (2017). Application of some research methods to determine the level of safety in municipalities. Procedia - social and behavioral sciences, 237, 242-248.

Svetlík, J., \& Vel'as, A. (2016). The safety training in the municipality. EDULEARN16, 8, 1350-1355.

Šoltés, V. \& Štofková, K. (2016). The impact of business environment on regional disparities. CBU international conference proceedings, 4, 187-191.

Štatistika kriminality v Slovenskej republike [Crime statistics of the Slovak republic]. Ministry of interior of the Slovak republic. Retrieved from http://www.minv.sk/?statistika-kriminality-v-slovenskej-republike-xml.

Štofko, S., \& Štofková, Z. (2011). The importance of education in personal property security area. EDULEARN11, 3, 50485051.

Štofková, Z., \& Štofko, S. (2016). Some indicators of quality of life in a globalized world. Globalization and its socioeconomic consequences, 16, 2127-2134. 